\title{
Inter-organizational trust as a statement of social proximity
}

\section{Anna Wasiluk ${ }^{1}$ iD, Fahime Sadat Saadatyar ${ }^{2}$}

\begin{abstract}
Bearing in mind the important role of trust in the creation and development of networks, including clusters, the main purpose of the paper was to assess the level of trust of the surveyed enterprises to competitors and cooperators, as well as to identify factors, which have an impact on the trust level. The text presents the results of the research collected in 317 Polish enterprises operating in four industries: construction, food, metal, and machinery, as well as wood and furniture. The basic method of data collection was a survey. The respondents in the study were only representatives of the management or owners of enterprises qualified for the study, possessing knowledge about interorganizational cooperation, the so-called key informants. The results presented in the text indicated low trust among both competitive and cooperating enterprises. The presented results do not inspire optimism in the scope of possibilities of creating and developing other network connections beside clusters. The deficit of Polish enterprises in terms of trust in other companies that are not even their competitors will limit not only their ability to establish cooperation with domestic but also foreign companies. The considerations carried out in the text contribute to better recognition of interorganizational trust issues in the context of networking, including clusters. Still, they are not free from certain restrictions, which result, in particular, from the methodological approach used and, primarily, from the inability to generalize the results. Therefore, an additional direction of further scientific research may be to undertake replication studies carried out on a representative sample. Interesting research topics also include conducting similar research not only in Poland but also in other countries, both similar and completely different from Poland. They would allow a better recognition and understanding of the impact of culture and context on building trust. It may also be interesting to identify universal contextual factors affecting trust and their impact on changes in the meaning and intensity of trust.
\end{abstract}

Keywords: inter-organizational trust, social proximity, networks, business cluster

\footnotetext{
1 Anna Wasiluk, Ph.D., Assistant Professor, Bialystok University of Technology, Faculty of Engineering Management, Tarasiuka 2, 16-001 Kleosin/Białystok, Poland, e-mail: a.wasiluk@pb.edu.pl (ORCID ID: 0000-0002-5980-333X).

2 Fahime Sadat Saadatyar, Ph.D., Postdoctoral researcher at Tehran University, Management Faculty 16th Azar St., Enghelab Sq., Tehran, Iran, e-mail: saadatyarf@gmail.com (ORCID ID: 0000-0002-6901-0907).
} 


\section{INTRODUCTION}

Contemporary management is distinguished by tensions, duality, contradictions, dialectics, and paradoxes (Bratnicka-Myśliwiec, 2016). On the basis of management sciences, inter-organizational cooperation is mentioned among the main and still current areas of scientific exploration. In a dynamically changing environment, cooperation is not seen as just one of the possible strategic options, but as an essential measure taken for survival and development (Tristão, 2016; Wasiluk \& Tomaszuk, 2018). Inter-organizational relationships are established and maintained with various partners, as well as with direct or indirect competitors (Wasiluk, 2017; Klimas \& Czakon, 2018). This type of relationship between entities, consisting of simultaneous occurrence of cooperation and competition, is called coopetition in the literature on the subject (Zakrzewska-Bielawska, 2014; Widelska, Michalczuk, \& Moczydłowska, 2014). It can, therefore, be assumed that this is an intermediate concept between "pure cooperation and pure competition" (Osarenkhoe, 2010; Gómez-Diaz, García-Garnica, \& Curiel-Avilés, 2019).

The 21st century was hailed as a century of networking, and this applies to both social and organizational relationships. The development of network structures and connections has become clearly noticeable in socio-economic systems (Czerewacz-Filipowicz, 2019). Besides technical and social infrastructure and efficient strategic management, a strong and widely developed network of internal and external links of entities is considered as one of the important factors conditioning their international competitiveness. Clusters are certainly the answer to contemporary challenges, often defined precisely by the criterion of network connections (van Dijk \& Sverisson, 2003; Lis \& Lis, 2014, p. 81). Willingness to cooperate by companies operating in the same industry is a prerequisite to create and develop clusters. These structures are currently perceived as carriers of innovation (Daniluk \& Tomaszuk, 2016) and improvement of the competitive position of both enterprises and the entire regions (Lis \& Lis, 2019).

"Networks" is a research space that is a part of a new network paradigm in management sciences. One of the important research implications is the challenge associated with the methods of initiating and coordinating the cooperation of all network actors (Czakon, 2015; Tomaszuk, 2017a). The related literature points out that the practice of inter-organizational cooperation is very difficult to implement (Fedorowicz, Gogan, \& Williams, 2007; Kaiser, 2011). Despite the entrepreneurs' awareness of the role and importance of cooperation, the relationships among cooperating entities are often weak, impermanent, and above all, characterized by an attempt to use and exploit a partner (Nowak, 2015; Jakimowicz \& Rzeczkowski, 2019). Legal 
requirements or contracts are not sufficient conditions to ensure effective cooperation. Its course is influenced by many factors with characteristics pertaining to both external and internal conditions (Daniluk, 2019). Among many effective factors which are investigated by many studies, the literature has highlighted the inter-firm trust as one of the most important factors (Wasiluk, 2018a; Saadatyar, Al-Tabbaa, Dagnino, \& Vazife, 2019).

Trust plays an important role in the concept of social proximity (Huber, 2012; Heringa, Horlings, van der Zouwen, van den Besselaar, \& van Vierssen, 2014). Although social proximity should not be seen as a key factor in the development of business operations, it can fundamentally facilitate (Paci, Marrocu, \& Usai, 2014) and make it difficult (Uzzi, 1997) to achieve the goals set by business entities. It should be emphasized, however, that being close to social proximity is a key factor for the transmission of tacit knowledge, which may be more critical for the development of enterprises compared to codified knowledge. As noted by Lis (2018, p. 113), social proximity - which was previously underestimated - is currently the second dimension of closeness in terms of the number of published works.

There is no doubt that trust between different market actors affects the value of the relationship between them. It should be emphasized, however, that it is not permanent but changes under the influence of various factors. Therefore, it seems important not only to conduct continuous research on it but also to analyze it taking into account many differentiating variables such as industry, age, or the size of entities that are parties to inter-organizational relations. The presented text contributes to filling this research gap. Bearing in mind the above considerations and the need to better recognize the problems related to inter-organizational trust in the context of creating network structures, including clusters, the main purpose of the paper was to assess the level of trust of the surveyed enterprises to competitors and cooperators, as well as to identify factors, which have an impact on the trust level. The presented analysis of the results includes divisions due to such variables as industry, age and size of the surveyed entities.

The article is theoretical and empirical. The structure of the paper is as follows: the second section reviews the theoretical and empirical literature on trust and business clusters as a type of network. The third section presents the research methods. The fourth section deals with the results of the empirical analysis and discusses those results. The last section concludes the whole paper, offering policy recommendations, and giving directions for further research. 


\section{LITERATURE REVIEW}

The literature review illustrates that firms belonging to clusters are likely to achieve superior innovation and economic performance (Marshall, 1920; Scott, 1998; Capello \& Faggian, 2005, Pe'er \& Keil, 2013; Negrusa, Rus, \& Sofica, 2014; Burger, Karreman, \& van Eenennaam, 2015; Garcia-Villaverde, Elche, Martinez-Perez, \& Ruiz-Ortega, 2017). However, within the extended literature, there was a lack of consensus about what makes this happen. A basic focus of contemporary studies on clusters was that geography, per se, does not guarantee firm success (Porter, 2000). In other words, co-localization is not the only reason for enhancing the clusterized firms' competitiveness (Boschma, 2005). Indeed, a wealth of empirical literature shows that one of elements of success for regional clusters is the fact that they facilitate the formation of local inter-organizational networks, which act as conduits of knowledge and innovation (Balland, 2012; Garcia-Villaverde et al., 2017; Wasiluk, 2016).

The literature review suggests that, during past years, researchers have sought to identify the mechanisms and drivers which build competitive advantages for clustered firms compared to the firms outside the clusters (Tan, 2006; Molina-Morales, Belso-Martinez, Mas-Verdu, \& Martinez-Chafar, 2015; Hervas-Oliver, Lieo, \& Cervello, 2017). Therefore, these studies have focused on the advantages and characteristics of networks formed in the clusters. In this regard, they have already zoomed out on knowledge management and innovation subjects aiming to understand the knowledge transfer process in networks and clusters (Hoffman, Lopes, \& Medeiros, 2014; Lai, Hsu, Lin, Chen, \& Lin, 2014; Tomaszuk, 2017b). Since, as one of the most important potentials of clustering, "innovation" has declared that SMEs are interested in the underlined competitive advantage of clusters (Elexa, Lesáková, Klementová, \& Klement, 2019). Because the knowledge transfer is specified as the main driver of innovative clusters (Casanueva, Castro, \& Galán, 2013), the focus of a volume of the literature has been on the facilitators of knowledge transfer (Hoffman, Lopes, \& Medeiros, 2014; Lai et al., 2014; Balland, Belso-Martínez, \& Morrison, 2016). The studies have explained that one of the irrefutable factors facilitating knowledge transfer and innovation is the proximity and cooperation which take place within co-localized companies (Porter, 2000; Felzensztein \& Gimmon, 2009; Molina-Morales et al., 2015). It means that the existing literature has confirmed the role of joint actions among colocalized firms in enabling them to better compete globally (Schmitz, 1995; Geldes, Felzensztein, Turkina, \& Duard, 2014).

Researchers have provided different definitions of proximity. In accordance with proximity definitions, several dimensions like social, cognitive, geographical, organizational, and institutional proximity were 
presented as well. Yet, some researchers have claimed that the geographical proximity is only one of several dimensions of proximity and that all the dimensions are essential in explaining positive externalities for co-localized companies (Boschma, 2005; Boschma \& Frenken, 2010). Recently, some research have highlighted the role of social proximity in promoting innovation and knowledge sharing (Geldes et al., 2014; Molina-Morales et al., 2015). These results stress the importance of social capital and trust in network dynamics within clusters, which has been emphasized as a factor for success leading to positive potentials in a cluster (Wasiluk, 2017). Those potentials include innovation and sharing information, knowledge, and ideas (Wasiluk \& Daniluk, 2013; Hoffman, Lopes, \& Medeiros, 2017; Hervas-Oliver, Lieo, \& Cervello, 2017). Studies underline that all of the cluster's positive potentials rely on trust as an essential base of social capital. Without this element, the cluster becomes dysfunctional in meeting the expectations and/or complying with its tasks (Kong, 2005; Garcia-Villaverde et al., 2017). Therefore, it is obviously the role of social capital and coopetition that has recently attracted great attention of different studies pertinent to clusters (Brekke, 2015). That is also because the results on the formation and development of effective links within clusters have not been optimistic. It has been firmly identified that the mere creation of a cluster does not release its innovative potential (Saadatyar et al., 2019). To make it happen, it is necessary to reach an openness to establish cooperation with all its actors, including competitors.

The contemporary increase in interest toward trust is both an effect of the development of the concept of social capital as well as the need to take into account the impact of the social environment on the results of the functioning of various entities operating in a complicated business environment (Moczydłowska, 2012). As Czakon (2012, p. 27) rightly stated, "economic activity is immersed in a social context, and social structures - next to norms - determine the economic behavior." Trust is presented as a source and a basic element of social capital that facilitates cooperation and enables access to shared resources (Sztompka, 2007). Without trust, almost no socioeconomic system can work properly (Gilbert, 2010, p. 169; Moczydłowska, Korombel, \& Bitkowska, 2017).

Despite the great interest in the issue of trust, there is no comprehensive definition of trust (Smarżewska, 2018, p. 187). The lack of a perfect definition of this concept is primarily due to the multidimensionality, complexity, and multifaceted nature of the analyzed concept (Wasiluk, 2018b). Consideration is given to such issues as what the concept of trust is. Is trust an action or rather an attitude, feeling, strategy, or behavior? Or is it a tactic that is geared towards a specific goal, or is it a kind of advance payment for future expected profits, connections, and benefits? Is the trust given to organizations, institutions, 
systems the same as the trust given to people in a family or circle of friends? (Lenk, 2010, pp. 28-29) The term trust is currently the subject of interest of representatives of various scientific disciplines such as philosophy, sociology, psychology, economics, management sciences, political sciences, and, more and more often, technical disciplines in particular (Ejdys, 2018, pp. 42-43).

Many empirical and statistical research results convey that mutual trust in business relationships promotes cooperation (Clases, Bachmann, \& Wehner, 2003; Gilbert, 2007; Gilbert \& Behnam, 2013; Brattström, 2018). Knowledge exchange and cooperation in networks, including clusters, are based on trust, and network actors play an important role in creating trustbased relationships. (Kumar, Banerjee, Meena, \& Ganguly, 2016; Giest, 2019). Trust between partners leads to a reduction of transaction costs (Dyer \& Chu, 2003; Paliszkiewicz, 2010) and the need for a precise specification of contracts and ultimately saves their excessive control (Gilbert, 2010, p. 186). It also positively affects the coordination of activities between members of a given organization (Fainshmidt \& Frazier, 2017). It should be emphasized that even effective trust can only partially replace the need for control, but it does not make it unnecessary (Lenk, 2010, p. 36).

Although the literature on the subject states that trust can be considered as an indispensable element of any network and a lack of trust is considered as a threat to network stability (Naramski \& Szromek, 2019, p. 4), some researchers recommend a critical approach to the level of trust. The fact that how much trust is optimal for a partner in a given case depends on his willingness to take risks, the context of the situation, and the duration and intensity of the current cooperation (Prisching, 2009). One should not accept the verdict that in all cases, the higher the level of trust, the better. Some examples can be cited when distrust was a better option for the behavior and brought positive results (Oomsels \& Bouckaert, 2014).

Despite the universal recognition of the importance of trust in interfirm relations, it remains a highly contextual phenomenon, sensitive to industrial and cultural contexts (Jucevicius \& Juceviciene, 2016). In addition, the literature on the subject points out that trust in inter-organizational relationships is variable. The importance and intensity of trust may vary, which relates to the probability with which expectations and the obligations of the other party can be met. In addition, trust is created and develops in conditions of voluntary and unforced cooperation. The existence of trust requires at least two acceptable solutions: positive and negative, the possibility of profit, but also the risk of loss (Grudzewski, Hejduk, Sankowska, \& Wańtuchowicz, 2009, p. 20). Trust is fragile. It takes a long time to build, but it is easily destroyed and difficult to recover (Wasiluk, 2015). 


\section{RESEARCH METHODS}

The analyses were to answer the following research questions (RQs):

RQ1. What is the level of trust of the surveyed enterprises for competition?

$R Q 2$. What is the level of trust of the surveyed enterprises to subcontractors?

$R Q 3$. Is there a relationship between the declared level of trust in competitors and the declared level of trust in subcontractors?

RQ4. Do variables such as the industry in which the enterprise operates, its age and size affect the declared level of trust in both competition and cooperators?

RQ5. What is the impact of the identified factors on the confidence level of the surveyed companies in competition?

The presented analyses are based on the results of extensive research (the co-author of this text was a member of the research team) conducted within an international research project implemented as part of an agreement between the Polish Academy of Sciences and the National Academy of Sciences of Belarus (in 2014-2016) entitled "Readiness of enterprises to create cross-border networking." The results of the quantitative research presented in this text relate to research carried out among 317 Polish enterprises operating in the industries of construction, food, metal, and machinery as well as wood and furniture. They were selected on the basis of data obtained at the Statistical Office in Bialystok. Most of them are micro and small enterprises - around $60 \%$ of surveyed companies. Considering the length of operation on the market, the enterprises operating for over 10 years showed the highest percentage (Table 1).

The results presented in the text apply only to quantitative research conducted using a questionnaire. The respondents in the study were only representatives of the management or owners of enterprises qualified for the study, possessing knowledge about inter-organizational cooperation, the so-called key informants (Kumar, Stern, \& Anderson, 1993). Identification of factors affecting trust was made on the basis of literature analysis as well as the results of discussions with experts representing both the scientific and business community. Finally, respondents were submitted for assessment of reliability and timeliness of information provided by competitors, corruption among competitors, competencies of employees of competitive companies, willingness to cooperate with competitors, reputation of competitors, experience from previous cooperation, credibility of competitors, reliability of competitors, competitiveness of competitors' activity, social responsibility of competitors, and emotionalities with competitors. 
Table1. Characteristics of the studied enterprises

\begin{tabular}{|c|c|c|c|c|}
\hline \multicolumn{5}{|l|}{ Enterprises } \\
\hline $\begin{array}{l}\text { Industry of the studied } \\
\text { enterprises }\end{array}$ & $\begin{array}{l}\text { construction } \\
\mathrm{N}(\%)\end{array}$ & $\begin{array}{l}\text { food } \\
N(\%)\end{array}$ & $\begin{array}{l}\text { metal and machinery } \\
\mathrm{N}(\%)\end{array}$ & $\begin{array}{l}\text { wood and } \\
\text { furniture } \mathrm{N}(\%)\end{array}$ \\
\hline Enterprises total N (\%) & $76(19.95)$ & $83(21.78)$ & $76(19.95)$ & $82(21.52)$ \\
\hline \multicolumn{5}{|c|}{ Size of the studied enterprises (number of employees) } \\
\hline Up to 9 people & $20(26.32)$ & $8(9.64)$ & $10(13.16)$ & $25(30.49)$ \\
\hline $10 \leq S \leq 49$ people & $23(30.26)$ & $40(48.19)$ & $26(34.21)$ & $42(51.22)$ \\
\hline $50 \leq S \leq 249$ people & $27(35.53)$ & $26(31.33)$ & $23(30.26)$ & $10(12.19)$ \\
\hline 250 people and more & $6(7.89)$ & $9(10.84)$ & $17(22.37)$ & $5(6.10)$ \\
\hline \multicolumn{5}{|c|}{$\begin{array}{l}\text { Age of the studied enterprises } \\
\text { (number of years on the market) }\end{array}$} \\
\hline Up to 1 year & $1(1.31)$ & $0(0.00)$ & $0(0.00)$ & $0(0.00)$ \\
\hline $1 \leq \mathrm{A} \leq 3$ years & $12(15.79)$ & $0(0.00)$ & $2(2.63)$ & $8(9.76)$ \\
\hline $4 \leq A \leq 10$ years & $15(19.74)$ & $13(15.66)$ & $13(17.11)$ & $13(15.85)$ \\
\hline More than 10 years & $48(63.16)$ & $70(84.34)$ & $61(80.26)$ & $61(74.39)$ \\
\hline
\end{tabular}

The respondents assessed the impact of individual factors on a sevenpoint scale, with 1 - indicating completely no impact, and 7 - being very large.

The collected empirical materials have been encoded and then subjected to conversion to numerical forms to allow carrying out detailed analyses of the surveyed group. The following statistical measures were used to interpret the results of the research: measures of central tendency - mean $(x)$, median $(M e)$, dominant $(D)$, and measure of dispersion - the coefficient of variation (V). To indicate the strength of interdependence between the ratings, Spearman's rank correlation coefficient was used. To identify statistically significant differences in the ratings between the analyzed groups, the Kruskal-Wallis test was used. Statistical calculations were made with the use of STATISTICA program version 13.1.

\section{RESEARCH RESULTS}

The respondents rated the level of trust of their enterprises to competition as low (RQ1). Average scores oscillated around 3. The lowest values occurred in the group of enterprises operating in the construction and metal and machinery industries, micro and medium enterprises, as well as those on the shortest market. The results indicated a poor diversity of respondents' opinions, and in the case of the youngest companies, it is even much weaker (Table 2). The average scores in the individual groups differ only slightly, and the results of the KruskalWallis test specified that these differences are not statistically significant (RQ4). 
Such results can be surprising, especially in the case of construction activities. Enterprises in this industry are forced to cooperate with competing companies, entering into consortia with them to implement investments, and it is often the only way to win a tender or receive an order to carry out an undertaking. However, the results of the analyses presented in other publications indicated a large deficit in terms of both current cooperation and readiness to tighten it in the near future, among industrial and construction enterprises. Therefore, it can be assumed that both the lack of skills to cooperate with other companies and the low level of trust among them can restrict their development opportunities and make it difficult to take advantage of emerging opportunities. It also negatively affects their competitive position on the international market. The low level of confidence in competition, as well as the lack of cooperation and the desire to strengthen it in the near future, will result in the inability to both create and develop existing clusters.

Table 2. Trust of surveyed enterprises to competition

\begin{tabular}{|c|c|c|c|c|}
\hline Statistical measures & $\mathbf{x}$ & Me & D & $\mathbf{V}$ \\
\hline \multicolumn{5}{|c|}{ Industry of the studied enterprises } \\
\hline construction & 2.94 & 3 & 3 & 43.23 \\
\hline food & 3.12 & 3 & 3 & 40.78 \\
\hline metal and machinery & 2.96 & 3 & 3 & 44.28 \\
\hline \multirow[t]{2}{*}{ wood and furniture } & 3.13 & 3 & 3 & 46.97 \\
\hline & \multicolumn{3}{|c|}{ Kruskal-Wallis test $\mathrm{H}=1.1273$} & \\
\hline \multicolumn{5}{|c|}{ Size of the studied enterprises (number of employees) } \\
\hline Up to 9 people & 2.96 & 3 & 3 & 43.68 \\
\hline $10 \leq \mathrm{P} \leq 49$ people & 3.07 & 3 & 3 & 46.19 \\
\hline $50 \leq P \leq 249$ people & 2.93 & 3 & 3 & 45.27 \\
\hline \multirow[t]{2}{*}{250 people and more } & 3.35 & 3 & 5 & 41.97 \\
\hline & \multicolumn{3}{|c|}{ Kruskal-Wallis test $\mathrm{H}=3.5211$} & \\
\hline \multicolumn{5}{|c|}{ Age of the studied enterprises (number of years on the market) } \\
\hline up to 1 year & 2.33 & 2 & 2 & 24. 74 \\
\hline $1 \leq A \leq 3$ years & 3.04 & 3 & 2 & 43.45 \\
\hline $4 \leq A \leq 10$ years & 2.94 & 3 & 3 & 49.49 \\
\hline \multirow[t]{2}{*}{ more than 10 years } & 3.06 & 3 & 3 & 44.19 \\
\hline & \multicolumn{3}{|c|}{ Kruskal-Wallis test $\mathrm{H}=1.7631$} & \\
\hline
\end{tabular}

It was interesting to check whether the level of trust among business partners differs from the level of trust among competitors (RQ2). The average rating was at level 4 . The lowest values occurred in the group of food enterprises, the smallest and the youngest. The summary of the results of the analysis (Table 3 ) showed that the respondents rated their companies' 
confidence among their partners higher as compared to their confidence confronting their competitors. Nevertheless, given the seven-point scale of the assessment, it is also not really high. The median in all analyzed groups is at level 4 , and the coefficient of variation indicates a weak differentiation in the respondents' ratings. Although, as in the case of assessments of confidence in competition, the average rating indicates there is a differentiation between individual groups. However, the results of the Kruskal-Wallis test indicated that these differences are not statistically significant (RQ4).

Table 3. Trust of the surveyed enterprises to subcontractors

\begin{tabular}{|c|c|c|c|c|}
\hline Statistical measures & $\mathbf{x}$ & Me & D & v \\
\hline \multicolumn{5}{|c|}{ Industry of the studied enterprises } \\
\hline construction & 4.08 & 4 & 5 & 35.53 \\
\hline food & 3.98 & 4 & 4 & 34.24 \\
\hline metal and machinery & 4.34 & 4 & $5 / 6$ & 31.59 \\
\hline \multirow[t]{2}{*}{ wood and furniture } & 4.11 & 4 & 4 & 38.04 \\
\hline & \multicolumn{3}{|c|}{ Kruskal-Wallis test (relevant at $\mathrm{p}<0.05000$ ) } & $H=2.9327 \quad p=0.4021$ \\
\hline \multicolumn{5}{|c|}{ Size of the studied enterprises (number of employees) } \\
\hline up to 9 people & 3.81 & 4 & 3 & 38.08 \\
\hline $10 \leq \mathrm{P} \leq 49$ people & 4.25 & 4 & 4 & 33.94 \\
\hline $50 \leq \mathrm{P} \leq 249$ people & 4.25 & 4 & 5 & 33.94 \\
\hline \multirow[t]{2}{*}{250 people and more } & 4.33 & 4 & 4 & 31.15 \\
\hline & \multicolumn{4}{|c|}{ Kruskal-Wallis test (relevant at $p<0.05000$ ) } \\
\hline \multicolumn{5}{|c|}{ Age of the studied enterprises (number of years on the market) } \\
\hline up to 1 year & 3.81 & 4 & 3 & 38.08 \\
\hline $1 \leq A \leq 3$ years & 4.29 & 4 & 4 & 35.28 \\
\hline $4 \leq A \leq 10$ years & 3.96 & 4 & 3 & 37.97 \\
\hline \multirow[t]{2}{*}{ more than 10 years } & 4.20 & 4 & 4 & 33.77 \\
\hline & \multicolumn{4}{|c|}{ Kruskal-Wallis test (relevant at $p<0.05000$ ) } \\
\hline
\end{tabular}

The presented results do not inspire optimism in the scope of possibilities of creating and developing other network connections beside clusters. The deficit of Polish enterprises in terms of trust in other companies that are not even their competitors will limit not only their ability to establish cooperation with domestic but also foreign companies. As mentioned earlier, the modern 
economy is network-based, and the competitive advantage of enterprises is determined by their ability to enter into cooperative systems.

The correlations of Spearman's ranks (Table 4) indicate that there is a positive relationship between the level of confidence among competitors and cooperators reported only in the group of the oldest enterprises operating in the construction and food industries and employing up to 249 people. This means that the higher the level of trust in competitors, the higher the level of trust in subcontractors. However, it should be noted that this relationship is very low (RQ3).

Table 4. Correlations of Spearman's ranks for evaluation of the trust of surveyed enterprises to competition and to subcontractors

\begin{tabular}{lc}
\hline $\begin{array}{l}\text { Companies } \\
\text { Industry of the studied enterprises }\end{array}$ & $\begin{array}{l}\text { Correlations of Spearman's ranks } \\
\text { (relevant at } p<0.05000)^{*}\end{array}$ \\
\hline construction & $\mathbf{0 . 2 3 3 9 1 0}$ \\
food & $\mathbf{0 . 2 6 5 1 7 5}$ \\
metal and machinery & 0.148443 \\
wood and furniture & 0.206551 \\
\hline Size of the studied enterprises (number of employees) \\
\hline up to 9 people & $\mathbf{0 . 2 8 2 0 0 8}$ \\
$10 \leq P \leq 49$ people & $\mathbf{0 . 1 7 5 6 6 0}$ \\
$50 \leq P \leq 249$ people & $\mathbf{0 . 3 1 0 5 9 6}$ \\
250 people and more & 0.226755 \\
\hline Age of the studied enterprises (number of years on the market) \\
\hline up to 1 year & - \\
$1 \leq \mathrm{A} \leq 3$ years & 0.329875 \\
$4 \leq \mathrm{A} \leq 10$ years & 0.091649 \\
more than $10 y e a r s$ & $\mathbf{0 . 2 6 6 3 4 2}$ \\
\hline Note: $*$ values in bold
\end{tabular}
Note: * values in bold. 
Table 5. Assessment of the impact of individual factors on the level of confidence in competition

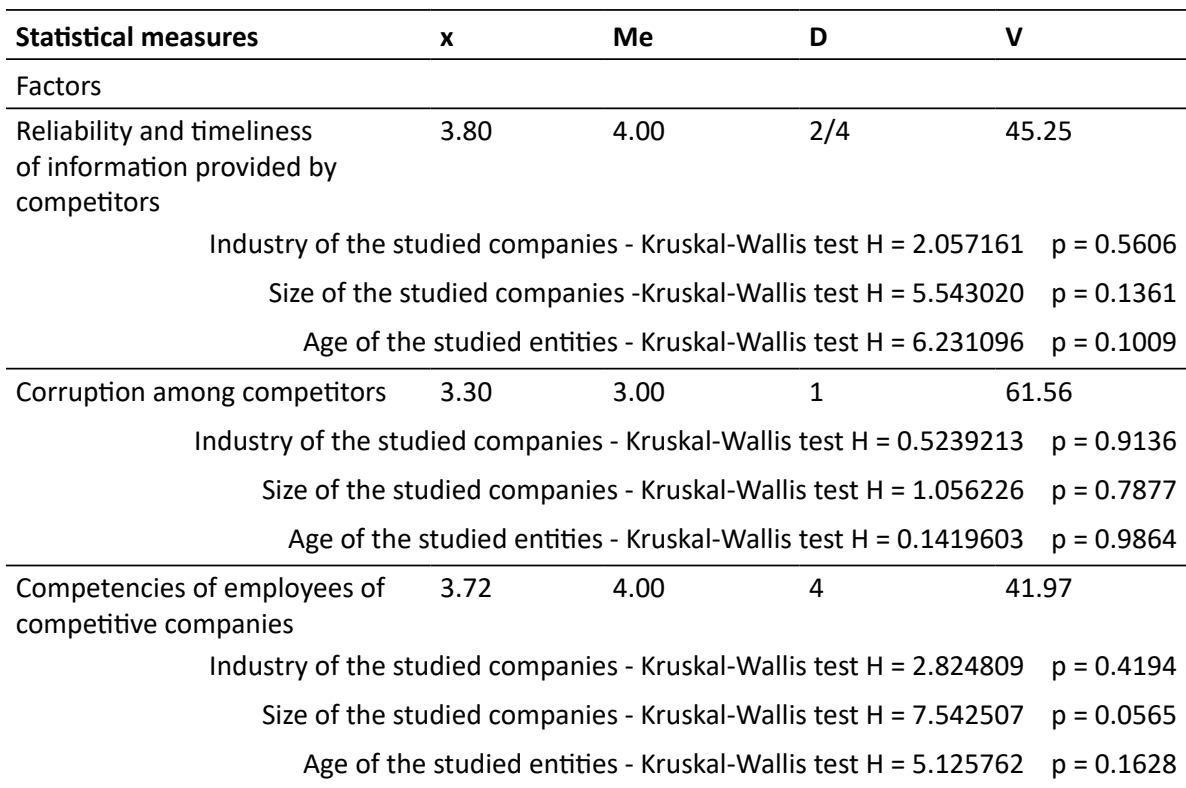

$\begin{array}{lllll}\text { Willingness to cooperate with } & 3.66 & 4.00 & 4 & 43.64\end{array}$ competitors

Industry of the studied companies - Kruskal-Wallis test $\mathrm{H}=2.706251 \quad \mathrm{p}=0.4392$

Size of the studied companies - Kruskal-Wallis test $\mathrm{H}=4.290678 \mathrm{p}=0.2317$

Age of the studied entities - Kruskal-Wallis test $\mathrm{H}=6.531526 \mathrm{p}=0.0884$

$\begin{array}{lllll}\text { Reputation of competitors } & 4.05 & 4.00 & 5 & 40.87\end{array}$

Industry of the studied companies - Kruskal-Wallis test $\mathrm{H}=1.204434 \quad \mathrm{p}=0.7519$

Size of the studied companies - Kruskal-Wallis test $\mathrm{H}=4.683535 \mathrm{p}=0.1965$

Age of the studied entities - Kruskal-Wallis test $\mathrm{H}=3.364538 \quad \mathrm{p}=0.3388$

$\begin{array}{lllll}\text { Experience from previous } & 4.12 & 4.00 & 4 & 43.61\end{array}$
cooperation

Industry of the studied companies - Kruskal-Wallis test $\mathrm{H}=2.758408 \quad \mathrm{p}=0.4304$

Size of the studied companies - Kruskal-Wallis test $\mathrm{H}=2.778887 \quad \mathrm{p}=0.4270$

Age of the studied entities - Kruskal-Wallis test $\mathrm{H}=2.152367 \quad \mathrm{p}=0.5414$

\begin{tabular}{lllll}
\hline Credibility of competitors & 4.17 & 4.00 & 5 & 44.53
\end{tabular}

Industry of the studied companies - Kruskal-Wallis test $\mathrm{H}=4.297808 \quad \mathrm{p}=0.2311$

Size of the studied companies - Kruskal-Wallis test $\mathrm{H}=3.827791 \quad \mathrm{p}=0.2807$

Age of the studied entities - Kruskal-Wallis test $\mathrm{H}=1.716460 \quad \mathrm{p}=0.6333$

$\begin{array}{lllll}\text { Reliability of competitors } & 4.14 & 4.00 & 4 & 43.47\end{array}$

Industry of the studied companies - Kruskal-Wallis test $\mathrm{H}=3.012930 \quad \mathrm{p}=0.3896$ 


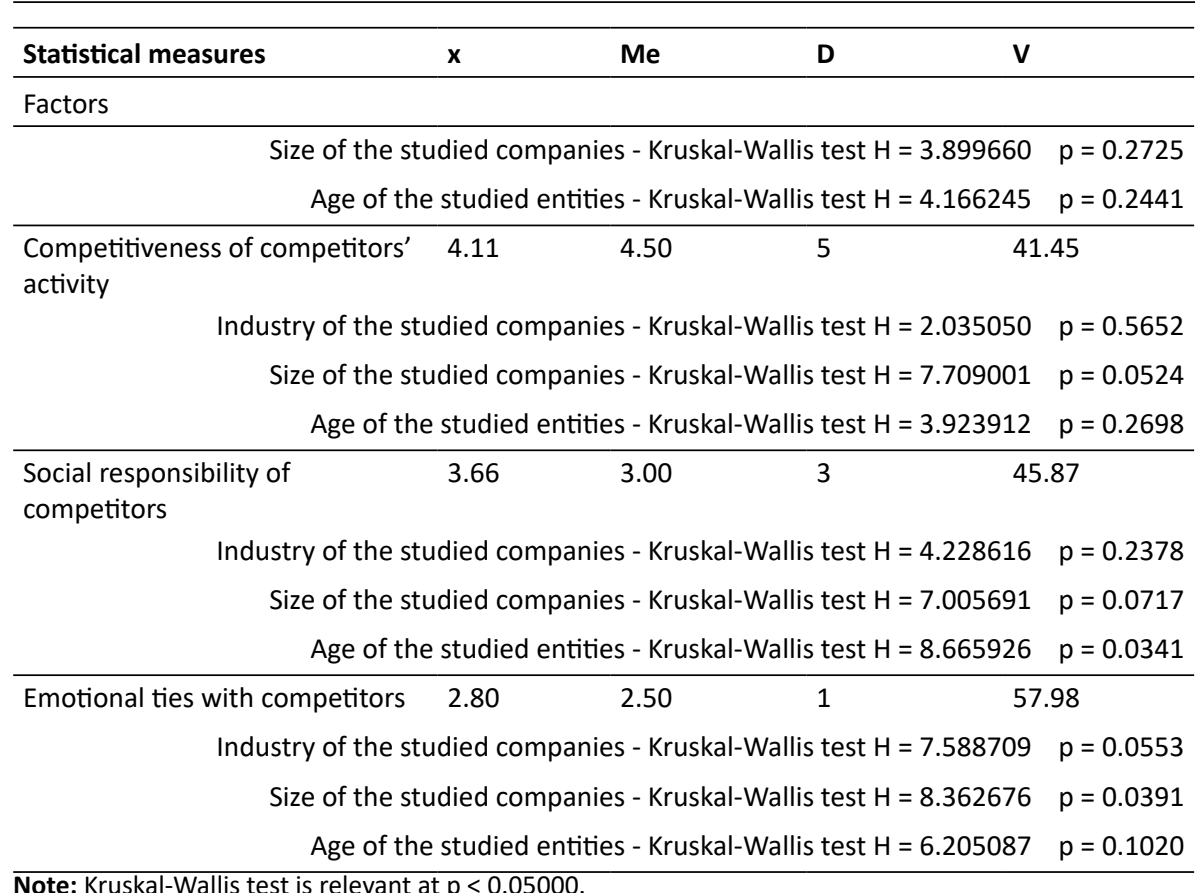

Investigating the impact of individual factors on the respondents' confidence in competition (RQ5), it was found that the transparency of competitors' activities $(x=4.11)$, their credibility $(x=4.17)$ and reliability $(x=4.14)$, as well as the experience from previous cooperation $(x=4.12)$ have the highest impact on the level of their enterprise's confidence among competing companies (Table 5). On the other hand, emotional ties with competitors $(x=2.80)$ and corruption among competitors $(x=3.30)$ were the least important factors. The volatility index indicates a moderate diversity in the respondents' ratings. The diversity of ratings was only high while assessing the impact of corruption among competitors. The results of the Kruskal-Wallis test carried out for the assessment of individual factors within the analyzed groups of respondents indicate that the differences in the assessment of individual factors are not statistically significant (RQ4).

It is surprising that the impact of emotional ties with competitors on the level of respondents' trust in these companies is low. The explanation for this state of affairs may be the fact that the surveyed enterprises rarely cooperated with competing enterprises, which certainly resulted in a lack of relations between them. 


\section{DISCUSSION}

The conducted analyzes allowed the realization of an answer to the research questions posed (RQ1). The surveyed entities rated their trust in competition low. The average scores oscillated around 3 on a seven-point scale. Higher respondents rated the level of trust of their companies to business partners - on average, at level 4 (RQ2). A positive correlation between the amount of assessment of the level of trust in competitors and cooperators occurs only in the group of the oldest enterprises operating in the construction and food industry and employing up to 249 people. The higher the level of trust in competitors, the higher the level of trust in subcontractors (RQ3). The transparency of their operations, credibility, and reliability, as well as experience from previous cooperation, had the highest impact on the level of trust of the surveyed enterprises in competing companies. Emotional ties with competitors and corruption among competitors (RQ5) were the least important. It should be noted that there are no statistically significant differences both in the assessment of the level of trust in competitors and contractors, and in the impact of individual factors on the level of trust within individual groups of enterprises (RQ4).

The research results presented in the text confirm the image presented in other publications. As noted by Czapliński (2015), one of the biggest weaknesses of the Polish economy is the low level of social capital. Although in the Legatum Institute report from 2018 (Legatum Institute, 2018), Poland is in the $33^{\text {rd }}$ position in the general classification of countries, it is only 76th in terms of social capital development. Meanwhile, as the literature emphasizes, social capital is a necessary condition to unleash the innovative potentials in clusters and other networks of enterprise connections. Sharing information, knowledge, and ideas requires trust (Hoffman, 2014; Lai et al., 2014; Garcia-Villaverde et al., 2017; Saadatyar, Al-Tabbaa, Dagnino, \& Vazife, 2019) and these structures become dysfunctional without this element, leading to failure in meeting expectations or fulfilling tasks. As emphasized by Chen, Haga, and Fong (2016), the lack of social capital means that the cooperation structures created are usually short-lived, because social capital is a kind of "glue" that holds them together.

The ability to cooperate is currently among the key factors to success for enterprises. Many authors have given emphasis to a lack of confidence in potential partners as the most important barriers to cooperation (Cook, Hardin, \& Lev, 2005; Fawcett, Magnan, \& McCarter, 2008). The literature on the subject emphasizes that participation in networks, including clusters, is based on voluntariness and not on coercion. That is why trust is such an important factor influencing the development of these structures. As 
mentioned in earlier parts of the text, cooperation is now seen not just as one of the possible strategic options, but as a necessary action to survive and develop companies. That is because the innovations rarely arise in individual enterprises. The ability of companies to create and introduce innovations increasingly depends on their ability to cooperate with other entities, including competitors (Cui \& Wei, 2012; Hemert, Nijkamp, \& Masurel, 2012). Inter-organizational cooperation in the sphere of innovation in both the value chain system and coopetitive cooperation increases the innovative efficiency of enterprises (Garanti \& Zvirbule-Berezina, 2013; Chick, Huchzermeier, \& Netessine, 2014). Network connections, in particular cluster networks, which facilitate access to innovation, even to enterprises with small financial and competence resources (Romanowska, 2016, p. 34), play a significant role in this regard. The results presented in the text indicated low trust among both competitive and cooperating enterprises. Therefore, one can conclude that this situation is not optimistic.

Seeking possible solutions to the problem, and bearing in mind both the literature analyses and the presented research results, it is worth paying attention to the Convoy model. This is a relatively new approach to the problem of increasing competitiveness in the region and is an attempt to develop and improve cluster theory. This model was created in response to the ineffectiveness of classical clusters, in the sense of Porter, in regions with low resources conducive to the development of innovative entrepreneurship (Bertolin, 2010). The main difference between a classic cluster and a grouping of companies in the Convoy model is that the network of companies is formed around a central company or institution within this model, in contrast to the classic model in which the cluster was defined as a relatively chaotic and even grouping of companies. The essential element of clusters in the Convoy model is the so-called "Locomotive," i.e. a leader in a given network (company or institution), which supplements deficiencies among companies in the environment regarding the factors determining their innovation. These are mainly resources, knowledge, and infrastructure. Unlike a classic cluster, the Convoy is a dynamic object thanks to the "locomotive" that triggers operations inside the network. It is also less chaotic. The central entity harmonizes the activities of all companies and tries to pull the whole group towards their long-term goals, which, given the limited resources of small companies operating alone, are often not even formulated (Rokosz, 2019). 


\section{CONCLUSION}

The issue of inter-organizational trust is an issue that is both current and relevant on the basis of both theoretical considerations and practical actions. The literature review carried out in the text allowed for the juxtaposition of both older and latest publications on the subject discussed. The new approach to the presented content allows a different view on the issues raised in the text and their different interpretation. The conducted considerations (both theoretical and empirical) contribute to filling the existing gap in research on inter-organizational trust in the context of networking, including clusters. This is especially about research that will allow you to understand the impact of context on building trust. Therefore, they can be a valuable source of inspiration for undertaking specific actions by various decision makers, including animators of various types of networks, including clusters. These activities should primarily focus on arranging face-to-face meetings. Direct contacts between network actors are conducive to strengthening personal relationships. The more frequent the contacts, the greater the chance for developing trust between the parties. It should be emphasized, however, that the research results presented in the text are not free from certain restrictions, which result, in particular, from the methodological approach used and, primarily, from the inability to generalize the results. Hence, an additional direction of further scientific research may be to undertake replication studies conducted on representative samples not only in Poland but also in other countries. Interesting research threads also include the identification of universal contextual factors affecting trust and their impact on changes in essence and intensity of trust. It is also necessary to undertake research on the directions of activities that facilitate building trust between various actors in the market game.

\section{References}

Balland, P.-A., Belso-Martínez, J.A., \& Morrison, A. (2016). The dynamics of technical and business knowledge networks in industrial clusters: Embeddedness, status, or proximity?, Economic Geography, 92(1), 3560. https://doi.org/10.1080/00130095.2015.1094370

Bertolin, J. A. (2010). Convoy model: The dynamic perspective of porter's cluster model. Retrieved from https://innovationmanagement. se/2010/12/08/convoy-model-the-dynamic-perspective-of-porterscluster-model/

Boschma, R.A. (2005). Proximityand innovation:Acriticalassessment. Regional Studies, 39(1), 61-74. https://doi.org/10.1080/0034340052000320887 
Boschma, R.A., \& Frenken, K. (2010). The spatial evolution of innovation networks: A proximity perspective. In R. Boschma \& R. Martin (Eds.), The Handbook of Evolutionary Economic Geography (pp. 120-135). Cheltenham: Edward Elgar Publishing. http://dx.doi. org/10.4337/9781849806497.00012

Bratnicka-Myśliwiec, K. (2016). Paradoks rentowności i konkurencyjności w zarządzaniu strategicznym rozwojem przedsiębiorstwa. Organizacja i Kierowanie, 4, 57-70.

Brattström, A. (2018). How to deal with and repair broken trust in an R\&D partnership. Technology Innovation Management Review, 8(9), 4-15. http://doi.org/10.22215/timreview/1182

Brekke, T. (2015). Entrepreneurship and path dependency in regional development. Entrepreneurship \& Regional Development, 27(3-4), 202218. https://doi.org/10.1080/08985626.2015.1030457

Burger, M.J., Karreman, B., \& van Eenennaam, F. (2015). The competitive advantage of clusters: Cluster organizations and greenfield FDI in the European life sciences industry. Geoforum, 65, 179-191. https://doi. org/10.1016/j.geoforum.2015.07.019

Capello, R., \& Faggian, A. (2005). Collective learning and relational capital in local innovation processes. Regional Studies, 39(1), 75-87. https://doi. org/10.1080/0034340052000320851

Casanueva, C., Castro, I., \& Galán, J. L. (2013). Informational networks and innovation in mature industrial clusters. Journal of Business Research, 66, 603-613. https://doi.org/10.1016/j.jbusres.2012.02.043

Chen, S-T., Haga, K.Y.A., \& Fong, C.M. (2016). The effects of institutional legitimacy, social capital, and government relationship on clustered firms' performance in emerging economies. Journal of Organizational Change Management, 29(4), 529-550. https://doi.org/10.1108/JOCM11-2015-0211

Chick, S.E., Huchzermeier, A., \& Netessine, S. (2014). Europe's solution factories. Harvard Business Review, 92(4), 111-115.

Cui, M., \& Wei X. (2012). Analysis for innovation performance of the enterprise in industrial cluster based on the network. In D. Zeng (Ed.), Advances in Computer Science and Engineering (pp. 443-450). Berlin Heidelberg: Springer. https://doi.org/10.1007/978-3-642-27948-5_59

Clases, C., Bachmann, R., \& Wehner, T. (2003). Studying trust in virtual organizations. International Studies of Management \& Organization, 33(3), 7-27. https://doi.org/10.1080/00208825.2003.11043687

Cook, K.S., Hardin, R., \& Lev, M. (2005). Cooperation without trust? New York: Russell Sage Foundation.

Czakon, W. (2012). Sieci w Zarzqqdzaniu Strategicznym. Warszawa: Oficyna a Wolters Kluwer.

Czakon, W. (2015). Sieci międzyorganizacyjne w naukach o zarządzaniu w kierunku sieciowych modeli biznesu. Studia Ekonomiczne. Zeszyty Naukowe Uniwersytetu Ekonomicznego w Katowicach, 217, 9-18. 
Czapliński, J. (2015). Stan społeczeństwa obywatelskiego. In J. Czapliński \& T. Panek (Eds.), Diagnoza Społeczna 2015. Warunki i Jakość Życia Polaków (pp. 332-372). Warszawa: Rada Monitoringu Społecznego.

Czerewacz-Filipowicz, K. (2019). The Eurasian economic union as an element of the belt and road initiative. Comparative Economic Research, 22(2), 23-37. http://doi.org/10.2478/cer-2019-0010

Daniluk, A., \& Tomaszuk, A. (2016). Cooperation between competing companies as a factor of technological entrepreneurship creation. In I. Simberova, O. Zizlavsky, \& F. Milichovsky (Eds.), ICEM'2016: Proceeding of Selected Papers, Smart and Efficient Economy: Preparation for the Future Innovative Economy (pp. 533-541). Brno: Brno University of Technology Faculty of Business and Management.

Daniluk, A. (2019). Supporting enterprise innovation by business environment institutions in Poland and Belarus. In H.M. Bilgin, H. Danis, E. Demir, \& U. Can (Eds.), Eurasian Business Perspectives. Proceeding of the 22th EBES Conference (pp. 65-81). Berlin: Springer International Publishing. https:// doi.org/10.1007/978-3-030-11872-3_5

Dyer, J.H., \& Chu, W.C. (2003). The role of trustworthiness in reducing transaction costs and improving performance: Empirical evidence from the United States, Japan, and Korea. Organizational Science, 14(1), 5768. https://doi.org/10.1287/orsc.14.1.57.12806

Ejdys, J. (2018). Zaufanie do Technologii w E-administracji. Białystok: Oficyna Wydawnicza Politechniki Białostockiej.

Elexa, L'., Lesáková, L'., Klementová, V. \& Klement, L. (2019). Identification of prospective industrial clusters in Slovakia. Engineering Management in Production and Services, 11(2), 31-42. https://doi.org/10.2478/emj2019-0009

Fainshmidt, S., \& Frazier, M.L. (2017). What facilitates dynamic capabilities? The role of organizational climate for trust. Long Range Planning, 50(5), 550-566. https://doi.org/10.1016/j.Irp.2016.05.005

Fawcett, S.E., Magnan, G.M., \& McCarter, M.W. (2008). Benefits, barriers, and bridges to effective supply chain management. Supply Chain Management: An International Journal, 13(1), 35-48. https://doi. org/10.1108/13598540810850300

Fedorowicz, J., Gogan, J.L., \& Williams, C. (2007). A collaborative network for first responders: Lessons from the CapWIN case. Government Information Quarterly, 24(4), 785-807. https://doi.org/10.1016/j.giq.2007.06.001

Felzensztein, C., \& Gimmon, E. (2009). Social networks and marketing cooperation in entrepreneurial clusters: An international comparative study. Journal of International Entrepreneurship, 7(4), 281-291. https:// doi.org/10.1007/s10843-009-0041-2

Garanti, Z., \& Zvirbule-Berezina, A. (2013). Regional cluster initiatives as a driving force for regional development. European Integration Studies, 7, 91-101. https://doi.org/10.5755/j01.eis.0.7.3677 
Garcia-Villaverde, P.M., Elche, D., Martinez-Perez, A., \& Ruiz-Ortega M.J. (2017). Determinants of radical innovation in clustered firms of the hospitality and tourism industry. International Journal of Hospitality Management, 61, 45-58. https://doi.org/10.1016/j.ijhm.2016.11.002

Geldes, C., Felzensztein, C., Turkina, E., \& Duard, A. (2014). How does proximity affect inter-firm marketing cooperation? A study of an agribusiness cluster. Journal of Business Research, 68(2), 263-272. https://doi. org/10.1016/j.jbusres.2014.09.034

Giest, S. (2019). Trust dynamics in innovation networks: The Chicago Life Science Cluster. Administration \& Society, 51(2), 325-343. https://doi. org/10.1177/0095399717701522

Gilbert, D.U., \& Behnam, M. (2013). Trust and the United Nations Global Compact: A network theory perspective. Business and Society, 52(1), 135-169. https://doi.org/10.1177/0007650312459852

Gilbert, D.U. (2007). Vertrauenals Gegenstand der ökonomischen Theorie (Ausgewählte theoretische Perspektiven, empirische Einsichten und neue Erkenntnisse). Zeitschrift für Management, 1, 60-107. https://doi. org/10.1007/s12354-007-0004-2

Gilbert, D.U. (2010). Entwicklungslinien der ökonomischen Vertrauensforschung. In M. Maring (Ed.), Vertrauen - zwischen sozialem Kitt und der Senkung von Transaktionskosten (pp. 169-198). Karlsruhe: KIT Scientific Publishing.

Gómez-Diaz, J., García-Garnica, A., \& Curiel-Avilés, G. (2019). Coopetencia, interaction of two antagonist relations. Dimensión Empresarial, 17(1), 130-137. http://dx.doi.org/10.15665/dem.v17i1.1506

Grudzewski, W.M., Hejduk, I.K., Sankowska, A., \& Wańtuchowicz, M. (2009). Zarządzanie Zaufaniem w Przedsiębiorstwie. Koncepcja, Narzędzia, Zastosowanie. Kraków: Oficyna a Wolters Kluwer business.

Hemert, P.V., Nijkamp, P., \& Masurel, E. (2012). From innovation to commercialization through networks and agglomerations: Analysis of sources of innovation, innovation capabilities and performance of Dutch SMEs. The Annals of Regional Science, 49(1), 1-28. https://doi. org/10.1007/s00168-012-0509-1

Heringa, P.W., Horlings, E., van der Zouwen, M., van den Besselaar, P., \& van Vierssen, W. (2014). How do dimensions of proximity relate to the outcomes of collaboration? A survey of knowledge-intensive networks in the Dutch water sector. Economics of Innovation and New Technology, 23(7), 689-716. https://doi.org/10.1080/10438599.2014.882139

Hervas-Oliver, J.-L., Lieo, M. \& Cervello, R. (2017). The dynamics of cluster entrepreneurship: Knowledge legacy from parents or agglomeration effects? The case of the Castellon ceramic tile district. Research Policy, 46(1), 73-92. https://doi.org/10.1016/j.respol.2016.10.006

Hoffmann, V. E., Lopes, G.S.C., \& Medeiros, J. J. (2014). Knowledge transfer among the small business of a Brazilian cluster. Journal of Business Research, 67(5), 856-864. https://doi.org/10.1016/j.jbusres.2013.07.004 
Huber, F. (2012). On the role and interrelationship of spatial, social and cognitive proximity: Personal knowledge relationships of R\&D workers in the Cambridge Information Technology Cluster. Regional Studies, 46(9), 1169-1182. https://doi.org/10.1080/00343404.2011.569539

Jakimowicz,A., \& Rzeczkowski, D. (2019). Diversification of innovation strategies of Polish industrial processing enterprises depending on their size after the global financial crisis. Journal of Entrepreneurship, Management and Innovation, 15(4), 35-76. https://doi.org/10.7341/20191542

Jucevicius, G., \& Juceviciene, R. (2016). Integrated approach to trust development in organizational networks. Academy of Management Annual Meeting Proceedings, 1, 1. https://doi.org/10.5465/ ambpp.2016.17080abstract

Kaiser, F.M. (2011). Interagency collaborative arrangements and activities: Types, rationales, considerations, congressional research service. Retrieved from https://fas.org/sgp/crs/misc/R41803.pdf

Klimas, P., \& Czakon, W. (2018). Organizational innovativeness and coopetition: A study of video games developers. Review of Managerial Science, 12(2), 469-497. https://doi.org/10.1007/s11846-017-0269-5

Kong, L.(2005). The sociality of cultural industries: Hong Kong's cultural policy and film industry. International Journal of Cultural Policy, 11(1), 61-76. https://doi.org/10.1080/10286630500067812

Kumar, G., Banerjee, R.N., Meena, P.L. \& Ganguly, K. (2016). Collaborative culture and relationship strength roles in collaborative relationships: A supply chain perspective. Journal of Business \& Industrial Marketing, 31(5), 587-599. https://doi.org/10.1108/JBIM-12-2014-0254

Kumar, N., Stern, L.W., \& Anderson, J.C. (1993). Conducting interorganizational research using key informants. Academy of Management Journal, 36(6), 1633-1651. https://doi.org/10.5465/256824

Lai, Y.-L., Hsu, M.-S., Lin, F.-J., Chen, Y.-M., \& Lin, Y.-H. (2014). The effects of industry cluster knowledge management on innovation performance. Journal of Business Research, 67(5), 734-739. https://doi.org/10.1016/j. jbusres.2013.11.036

Legatum Institute. (2018). The Legatum Prosperity Index 2018. Retrieved from https://www.prosperity.com

Lenk, H. (2010). Vertrauen als relationales Interpretations- und Emotionskonstrukt. In M. Maring (Ed.), Vertrauen - zwischen sozialem Kitt und der Senkung von Transaktionskosten (pp. 27-44). Karlsruhe: KIT Scientific Publishing.

Lis, A.M. (2018). Współpraca w Inicjatywach Klastrowych. Rola Bliskości w Rozwoju Powiqzań Kooperacyjnych. Gdańsk: Wydawnictwo Politechniki Gdańskiej.

Lis, A.M., \& Lis, A. (2014). Zarządzanie Kapitałami w Klastrach: Kapitał Społeczny, Kulturowy, Ekonomiczny i Symboliczny w Strukturach Klastrowych. Warszawa: Difin. 
Lis, A.M., \& Lis, A. (2019). To meet or to connect? Face-to-face contacts vs. ICT in cluster organisations. Engineering Management in Production and Services, 11(4), 103-117. https://doi.org/10.2478/emj-2019-0037

Marshall, A. (1920). Principles of Economics. London: Macmillan.

Moczydłowska, J.M., Korombel, A., \& Bitkowska, A. (2017). Relacje jako Kapitał Organizacji. Warszawa: Difin.

Moczydłowska, J.M. (2012). Zaufanie jako determinanta relacji przedsiębiorcy przedstawiciele administracji publicznej. Zarzqdzanie i Finanse, 4(2), 75-86.

Molina-Morales, F.X., Belso-Martinez, J. A., Mas-Verdu, F., \& Martinez-Chafar, L. (2015). Formation and dissolution of inter-firm linkages in lengthy and stable networks in clusters. Journal of Business Research, 68(7), 15571562. https://doi.org/10.1016/j.jbusres.2015.01.051

Naramski, M., \& Szromek, A.R. (2019). Configuring a trust-based interorganizational cooperation network for post-industrial tourist organizations on a tourist route. Sustainability, 11(13):3542, 1-20. https://doi.org/10.3390/su11133542

Negrusa, A.L., Rus, R.V., \& Sofica, A. (2014). Innovative tools used by business networks and clusters in communication. Procedia Social and Behavioral Sciences, 148. 558-595.

Nowak, D. (2015). Bariery rozwoju relacji kooperacyjnych. Problemy Zarzqdzania, 13(1(50), 47-67. https://doi.org/10.1016/j.sbspro.2014.07.084

Oomsels, P., \& Bouckaert, G. (2014). Studying interorganizational trust in public administration: A conceptual and analytical framework for "administrational trust." Public Performance \& Management Review, 37(4), 577-604. https://doi.org/10.2753/PMR1530-9576370403

Osarenkhoe, A. (2010). A coopetition strategy - a study of inter-firm dynamics between competition and cooperation. Business Strategy Series, 11(6), 343-362. https://doi.org/10.1108/17515631011093052

Paci, R., Marrocu E. \& Usai, S. (2014). The complementary effects of proximity dimensions on knowledge spillovers. Spatial Economic Analysis, 9(1), 9-30. https://doi.org/10.1080/17421772.2013.856518

Paliszkiewicz, J.O. (2010). Zaufanie a wyniki działalności przedsiębiorstw przegląd literatury. Zeszyty Naukowe SGGW w Warszawie. Ekonomika i Organizacja Gospodarki Żywnościowej, 82, 5-16.

Pe'er, A., \& Keil, T. (2013). Are all startups affected similarly by clusters? Agglomeration, competition, firm heterogeneity and survival. Journal of Business Venturing, 28(3), 354-372. https://doi.org/10.1016/j. jbusvent.2012.03.004

Porter, M.E. (2000). Location, competition, and economic development: Local clusters in a global economy. Economic Development Quarterly, 14(1), 15-34. https://doi.org/10.1177\%2F089124240001400105

Prisching, M. (2009). Strategien zur Beseitigung von Vertrauen. Wirtschaftspolitische Blätter, 2, 167-181.

Rokosz, W. (2019). Model konwoju jako skuteczny mechanizm transferu wiedzy z gniazd innowacji do gospodarki Polski. Przegląd Organizacji, 5, 16-25. 
Romanowska, M. (2016). Determinanty innowacyjności polskich przedsiębiorstw. Przeglad Organizacji, 2, 29-35.

Saadatyar, F.S., Al-Tabbaa, O., Dagnino, G.B., \& Vazife, Z. (2019). Industrial clusters in the developing economies: Insights from the Iranian carpet industry. Strategic Change, 28(6). https://doi.org/10.1002/jsc.2324

Schmitz, H. (1995). Collective efficiency: Growth path for small scale industry. Journal of Development Studies, 31(4), 529-566. https://doi. org/10.1080/00220389508422377

Scott, A.J. (1998). Regions and the World Economy the Coming Shape of Global Production, Competition, and Political Order. New York: Oxford University Press.

Smarżewska, D. (2018). Uwarunkowania lojalności pracowników wobec organizacji - aspekty teoretyczne. Przedsiębiorczość i Zarzq̨dzanie, 19(8(1)), 183-195.

Sztompka, P. (2007). Zaufanie. Fundament Społeczeństwa. Kraków: Znak.

Tan, J. (2006). Growth of industry clusters and innovation: Lessons from Beijing Zhongguancun Science Park. Journal of Business Venturing, 21(6), 827-850. https://doi.org/10.1016/j.jbusvent.2005.06.006

Tomaszuk, A. (2017a). Cooperation of businesses with business environment institutions (using Polish and Belorussian business as a case study). In 26th International Scientific Conference on Economic and Social Development - "Building Resilient Society". Book of Proceedings (pp. 232-243). Zagreb: Varazdin Development and Entrepreneurship Agency.

Tomaszuk, A. (2017b). Importance of technological factors in the creation of cooperation. Procedia Engineering, 182, 701-708. https://doi. org/10.1016/j.proeng.2017.03.183

Tristão, H., Oprime, P., \& Pimenta, M. (2016). Characteristics of relationships, types and strategies in a Brazilian cluster. International Journal of Productivity and Performance Management, 65(4), 485-502. https://doi. org/10.1108/IJPPM-09-2014-0149

Uzzi, B. (1997). Social structure and competition in inter-firm networks: The paradox of embeddedness. Administrative Science Quarterly, 42(1), 35-67.

van Dijk, M.P., Sverrisson, Á. (2003). Enterprise clusters in developing countries: Mechanisms of transition and stagnation. Entrepreneurship \& Regional Development, 15(3), 183-206. https://doi. org/10.1080/08985620210159239

Wasiluk, A., \& Daniluk, A. (2013). The possibilities of creating cross-border clusters. Vilnius: Vilnius University Publishing House.

Wasiluk, A. (2015). Zaufanie we współczesnym zarządzaniu. In A. Kowalczewska (Ed.), Wybrane Zagadnienia Miękkiego Zarzq̨dzania Organizacjami (pp. 57-77). Warszawa: Ementon.

Wasiluk, A. (2016). Trust and areas of cooperation between companies and institutions of science. In I. Simberova, O. Zizlavsky, \& F. Milichovsky (Eds.), ICEM'2016: Proceeding of Selected Papers, Smart and Efficient Economy: 
Preparation for the Future Innovative Economy (pp. 629-636). Brno: Brno University of Technology Faculty of Business and Management.

Wasiluk, A. (2017). Pro-innovative prerequisites for establishing the cooperation between companies (in the perspective of creation and development of clusters). Procedia Engineering, 182, 755-762. https:// doi.org/10.1016/j.proeng.2017.03.195

Wasiluk, A. (2018a). The influence of trust and previous experience on cooperation of enterprises - an empirical study in Poland and the Republic of Belarus. In M. Okręglicka, A. Korombel, \& A. Lemańska-Majdzik (Eds.), Proceedings of the 2nd International Conference Contemporary Issues in Theory and Practice of Management: CITPM 2018 (pp. 689694). Częstochowa: Czestochowa University of Technology. Faculty of Management.

Wasiluk, A. (2018b). Zaufanie a współpraca przedsiębiorstw w perspektywie tworzenia powiązań sieciowych. Przeglad Organizacji, 3, 30-34.

Wasiluk, A., \& Tomaszuk, A. (2018). Strategie relacyjne jako strategie współdziałania przedsiębiorstw - ujęcie teoretyczne. Akademia Zarzq̨izania, 2(4), 73-83.

Widelska, U., Michalczuk, G., \& Moczydłowska, J.M. (2014). Competition and cooperation as determinants of relational capabilities companies in electronic trade and services sector (based on the example of the Podlaskie province). Economy \& Business, 8, 742-751.

Zakrzewska-Bielawska, A. (2014). Wstęp. In A. Zakrzewska-Bielawska (Ed.), Koopetycja w Rozwoju Przedsiębiorstw High-Tech. Determinanty i Dynamika (pp. 6-9). Warszawa: Placet.

\begin{abstract}
Abstrakt
Biorqc pod uwagę istotnq rolę zaufania w tworzeniu i rozwoju sieci, w tym klastrów, głównym celem tekstu było zidentyfikowanie zwiqzku między poziomem zaufania badanych przedsiębiorstw do konkurentów i kooperantów oraz określenie wpływ zidentyfikowanych czynników na poziom tego zaufania. Tekst prezentuje wyniki badań zebrane w 317 polskich przedsiębiorstwach działajqcych w czterech branżach: budowlanej, spożywczej, metalowej i maszynowej oraz drzewnej i meblarskiej. Podstawowa metoda gromadzenia danych była ankieta. Respondentami w badaniu byli przedstawiciele kierownictwa lub właściciele przedsiębiorstw zakwalifikowanych do badania, posiadajacy wiedzę na temat współpracy międzyorganizacyjnej, tzw. kluczowi informatorzy. Wyniki przedstawione w tekście wskazuja na niskie zaufanie zarówno wśród przedsiębiorstw konkurencyjnych, jak i współpracujqcych. Prezentowane wynikiniebudzqoptymizmu wzakresie możliwościtworzeniairozwijania połaczeń sieciowych, w tym również klastrów. Deficyt polskich przedsiębiorstw pod względem zaufania do innych firm, które nawet nie sq ich konkurentami, ograniczy nie tylko ich zdolność do nawiqzania wspótpracy z firmami krajowymi, ale także zagranicznymi. Należy podkreślić, że choć rozważania przeprowadzone w tekście przyczyniaja się do lepszego rozpoznawania problemów zwiqzanych z zaufaniem
\end{abstract}


między organizacjami $w$ kontekście tworzenia sieci, w tym klastrów, to nie sq one wolne od pewnych ograniczeń. Wynika to w szczególności z zastosowanego podejścia metodologicznego i skutkuje przede wszystkim niezdolnościq do uogólnienia wyników. Dlatego dodatkowym kierunkiem dalszych badań naukowych może być podjęcie badań replikacji przeprowadzonych na reprezentatywnej próbie przedsiębiorstw. Interesujqce tematy badawcze obejmujq również prowadzenie podobnych badań nie tylko w Polsce, ale także $w$ innych krajach, zarówno podobnych, jak i zupełnie innych niż Polska. Umożliwiłyby one lepsze rozpoznanie i zrozumienie wpływu kultury i kontekstu na budowanie zaufania. Interesujqce może być również podjęcie próby określenia uniwersalnych czynników kontekstowych wpływajq̨cych na zaufanie oraz ich wpływ na jego zmiany i intensywność.

Słowa kluczowe: zaufanie międzyorganizacyjne, bliskość społeczna, sieci, klastry

\section{Biographical notes}

Anna Wasiluk, Ph.D. in economics in the field of management science. She works at the Faculty of Engineering Management of the Bialystok University of Technology. Her scientific research focuses on leadership, trust, cooperation, networks, and business clusters.

Fahime Sadat Saadatyar, Ph.D. and an independent researcher. Her main research interests are in two fields. First, she focuses on the area of industrial clusters and regional development, especially in developing countries. As a second research field, Fahime investigates organizational behavior aspects, including social capital and commitment.

\section{Conflicts of interest}

The authors declare no conflict of interest.

\section{Citation (APA Style)}

Wasiluk, A., \& Saadatyar, F.S. (2020). Inter-organizational trust as a statement of social proximity. Journal of Entrepreneurship, Management and Innovation, 16(3), 77-100. https://doi.org/10.7341/20201633 